\title{
ВИКОРИСТАННЯ МЕТОДИЧНИХ ПРИЙОМІВ ДЛЯ СТИМУЛЯЦІЇ КЛІНІЧНОГО МИСЛЕННЯ СТУДЕНТІВ МЕДИЧНОГО КОЛЕДЖУ
}

\author{
Ю. С. Старова
}

\author{
Київський міський медичний фаховий коледж
}

У статті запропоновано методи активізації пізнавальної діяльності студентів, висвітлено переваги проведення бінарних занять, проблемних лекцій та інших педагогічних технологій для розвитку в майбутньої медичної сестри критичного та клінічного типів мислення.

\section{USE OF METHODICAL TECHNIQUES TO STIMULATE CLINICAL THINKING OF STUDENTS OF A MEDICAL COLLEGE}

\author{
Yu. S. Starova \\ Kyiv Municipal Medical Professional College
}

The article describes techniques that stir up cognitive activity of students and highlights the benefits of conducting binary classes, problem lectures, and other pedagogical technologies for the development of critical and clinical thinking of future nurses.

Навчання без роздумів - шкідливе, роздуми без навчання - небезпечні Конфуцій

Вступ. Згідно з вимогами Державних стандартів вищої освіти, сучасний випускник медичного коледжу має бути досвідченим, професійно компетентним та конкурентоспроможним фахівцем. Той рівень медичної компетенції, який студент отримує у закладі вищої освіти (ЗВО), завтра буде наданий пацієнтам. Завдяки проведенню ліцензійного тестового іспиту «Крок М. Сестринська справа» для медичних сестер постійно підвищується якість освіти з підготовки майбутнього фахівця [1]. Ліцензійний іспит «Крок М» оцінює вміння використовувати знання та розуміння головних найважливіших професійно-орієнтованих дисциплін. Це обов'язкова складова атестації за програмою молодшого спеціаліста. За весь період навчання в медичному закладі викладачі Київського міського медичного фахового коледжу завзято тренують студентів медсестринського факультету розвивати в собі критичне та клінічне мислення шляхом поєднання різних форм педагогічного контролю. 3 метою якісної підготовки до складання () Ю. С. Старова, 2021 ліцензійного тестового іспиту можна застосувати багато методів для стимуляції клінічного мислення студента. Серед них потрібно назвати такі, як:

- проведення бінарних занять;

- застосування методичного прийому «Фішбоун»;

- виконання науково-дослідних робіт;

- проведення проблемних лекцій;

- використання структурно-логічних схем.

Основна частина. Головною метою, яку ставить перед собою кожен викладач, $є$ зацікавлення слухачів матеріалом лекційного чи практичного заняття. Для того, щоб привернути увагу студентів потрібно активно використовувати інтерактивні форми та інноваційні методи навчання. Однією з інтерактивних форм проведення занять в будь-якому навчальному закладі $є$ бінарне заняття, за своїм визначенням - це педагогічна технологія, одна з форм інтеграції предметів та реалізації міжпредметних зв'язків. Переваги використання бінарних занять такі:

- сприяють систематизації знань у студентів та більш якісному засвоєнню навчального матеріалу; 
- розвивають зацікавленість у вивченні дисциплін фахового спрямування;

- формують навички самоосвіти;

- активізують емоційну та логічну пам'ять;

- підвищують інтенсивність зосередження на об'єкті, що є важливим етапом формування студентського мислення.

3 міждисциплінарною інтеграцією тісно пов'язане поняття «компетенція» фахівця, що складається із сукупності знань, вмінь, бездоганності виконання практичних навичок і особистісних якостей студента, які він власне синтезує та інтегрує в процесі навчання. Особистісні та професійні компетентності майбутнього медика включають здатність оцінювати ризики, приймати рішення, вирішувати проблеми і реагувати на зміни, які постійно виникають в його практичній діяльності [2]. Поняття «клінічне мислення» позначає процес інтелектуальної обробки інформації про хворого (включає відомості з анамнезу, додаткових методів обстеження та необхідного для пацієнта лікування), а також чітке розуміння конкретної клінічної ситуації. Практичне мислення медичного працівника ґрунтується на знаннях, досвіді та професійній інтуїції.

Водночас із розумінням сутності клінічного мислення необхідно відзначити й роль критичного мислення для подальшого формування високих інтелектуальних здібностей медичної сестри [3]. Під критичним мисленням розуміють систему суджень, яка використовується для аналізу речей та подій з формулюванням обґрунтованих висновків і дозволяє виносити стверджені оцінки, інтерпретації та застосовувати отримані результати до ситуацій і проблем [4]. Відмінна риса критичного мислення постійно ставити під сумнів інформацію, що надходить. Навчити студентів критично мислити означає правильно формулювати запитання до хворого в процесі збору відомостей для уточнення та встановлення діагнозу, бути спостережливими, аналізувати та порівнювати дані лабораторних та клінічних досліджень, робити висновки, проводити диференційну діагностику, визначати мету і сестринські втручання для вирішення проблеми і т. д.

Розвиток критичного мислення у майбутнього медичного працівника виноситься на перший план, адже вміння критично мислити є запорукою ефективної практичної діяльності [5]. Усі активні та інтерактивні методи навчання покликані вирішувати головне завдання - навчити студента вчитися. Дуже важливим фактором стає розвиток критичного мислення, основаного на аналізі ситуації, самостійному пошуку інформації, побудові логічного ланцюжка та на прийнятті зваженого й аргументованого рішення. Завдяки проведенню бінарних занять можна навчити студента вести конструктивний діалог або дискусію, відстоювати власну точку зору, навчити культурі спілкування, розвинути логічне та образне мислення. Бінарне заняття $\epsilon$ потужною педагогічною технологією, адже інформація, що сприйнята 3 емоціями, запам'ятовується надовго та легше переводиться з довгострокової пам'яті в оперативну [6]. На сучасному рівні інтерактивних технологій можна проводити бінарні заняття з таким викладацьким складом, який перевищує стандартних двох викладачів - до співпраці залучають три або навіть й чотири доповідачі. Цікаво та незвично легко для сприйняття об'ємного матеріалу викладають в нашому коледжі дисципліни зуботехнічного факультету, вдало поєднують навчальну інформацію з різних точок зору також фахівці з основ медсестринства, анатомії та фізіології, фармакології, медсестринства в терапії, хірургії та педіатрії. Беручи участь в теоретичному або практичному комплексному бінарному занятті, студент має можливість інтегрувати знання з різних галузей медицини для вирішення однієї проблеми, вдосконалити власну компетентність, отримати мотивацію до вивчення конкретного питання та використати отримані знання на практиці [7].

Не можна не згадати усім добре знайомий метод «Фішбоун», як один з методичних прийомів, який спрямований на розвиток критичного мислення студентів у наочно-змістовній формі. Він дає можливість розвивати навички роботи з інформацією, вміння виявляти проблеми та знаходити шляхи їх вирішення. Цей метод широко використовують викладачі клінічних дисциплін у нашому коледжі, він дуже подобається аудиторії та залучає до роботи на занятті навіть слабких студентів. Найбільш ефективно схему «Риб'ячого скелета» можна використати на предметах «Медсестринство в хірургії», «Медсестринство в терапії» та «Медсестринство в педіатрії», адже метод дозволяє наочно зобразити матеріал окремої теми, виділити головні поняття та логічні зв'язки між ними й таким чином скоротити об'єм інформації, яка необхідна для запам'ятовування. Також студенти отримують додаткові навички роботи з інформацією, вчаться працювати в команді при вирішенні та дослідженні проблеми, розвивають в собі комунікативні компетенції.

Для ініціації процесів пізнавальної діяльності студентам пропонують такі методи педагогічного 
контролю, як вирішення атипових, нестандартних клінічних ситуацій у вигляді задач, тестів, науково-дослідних робіт та питань з теми різного рівня складності.

3 цього переліку методів особливо потрібно виділити роль науково-дослідних робіт у процесі стимуляції клінічного мислення. Наукова творчість стає наразі не тільки традиційним засобом розвитку майбутнього спеціаліста, а ще й розвиває уміння пошукової, дослідницької діяльності та творчого розв'язання певних наукових проблем [8]. Студенти набувають досвіду вивчення та критичного аналізу наукової літератури, їх навчають аргументувати свої висновки, здійснювати якісний і кількісний аналіз отриманих результатів дослідження та оформляти їх належним чином.

Проблемна лекція - це творчий процес взаємодії викладача з його аудиторією. Головною умовою творчого засвоєння знань $є$ пошук істини в проблемній ситуації. Особливо ефективною стає проблемна лекція в малих аудиторіях - до 30 осіб. Викладач обов'язково повинен забезпечити лекцію дидактичними матеріалами - аудіовізуальними засобами, мультимедійною системою, макетами, плакатами, муляжами тощо. Ці засоби потрібні для демонстрації різних етапів проблемної лекції - спочатку для створення проблемної ситуації, далі для вирішення навчальних проблем, й наприкінці, для підтвердження сформульованих висновків. Даний тип лекції значно підвищує роль логіко-методологічної функції, тобто розв'язання та розгляд наукових питань, які досі не мають вирішення; на таких лекціях студенти постійно знаходяться в процесі спільних роздумів із лектором, що приводить до позитивних результатів: активно засвоєні знання більш глибоко запам'ятовуються та мають ефект розвитку творчого мислення (перенесення даних знань в інші ситуації); сприяють підвищенню інтелекту (розвивальний ефект) та збільшують зацікавленість слухача до змісту матеріалу. Завдання педагога включає необхідність забезпечити участь студентів в аналізі протиріччя, яке виникає, залучити їх до вирішення проблемних ситуацій, навчити висувати оригінальні шляхи їх вирішення та аналізувати отриману інформацію у світі визначених теорій, висувати гіпотези і випробовувати різні методи для їх вирішення [9]. В основі проблемного навчання знаходиться проблемна ситуація, яка спонукає оволодіти раніше невідомими способами поведінки та мислення. У разі створення проблемної ситуації той, хто навчається, самостійно відкриває для себе нове в аналогії з вченим, який здійснив винахід. Водночас вирішується й головне завдання проблемної лекції - студент відволікається від механічного конспектування навчального матеріалу та долучається до активної пізнавальної діяльності [10].

Проблемна лекція має достатньо високу дидактичну ефективність, про що можуть свідчити добрі показники постлекційного тестового контролю за умов підвищеного ступеня мотивації у студентів.

Для розвитку творчого рівня пізнання бажано обирати таку структуру тесту, в запитальній частині якого $є$ словосполучення типу «які ускладнення слід очікувати у разі ...» або «оберіть низку невідкладних заходів при ...», або «вкажіть перелік незалежних сестринських втручань» та інші. За допомогою подібних тестів вдається діагностувати вміння студентів розв'язувати проблемні ситуації, відтворювати чи вирішувати неординарні й різноманітні за клінічним складом професійні завдання, які можуть траплятися в роботі медичного працівника [11]. Також тестовий контроль дає змогу застосовувати проблемні та навчально-програмні лекції для формування самостійного творчого мислення студентів, зростання якості їх навчання та забезпечення індивідуального підходу до кожного слухача. Можна при проведенні тестового контролю пропонувати відкриту форму тестів - це передбачає вільно конструйовану відповідь студентів, а сам тип тесту спонукає до розвитку аналітичного мислення в того, хто шукає правильного вирішення завдання.

Нарешті, структурно-логічна схема як один з ефективних методичних прийомів педагогічної практики допомагає слухачам краще освоювати тему, аналізувати смислові фрагменти графічного зображення, що в результаті призводить до спрощення систематизації навчального матеріалу для розуміння студента. Структурно-логічні схеми для теоретичних та практичних занять повинні суттєво відрізнятися за своєю побудовою. Наприклад, у процесі читання лекції схему можна продемонструвати на великому екрані або ж запропонувати студентам у вигляді роздаткового матеріалу. Зміст схеми має бути побудований з мінімальними поясненнями та текстовим супроводженням, таким чином студенти уважно стежитимуть за ходом лекції та виявлятимуть питання, які не висвітлені в темі. Відсутня інформація автоматично засвоїться яскравіше, ніж та, яка вже була надана в схемі. Структурно-логічні схеми для практичних занять мають бути більш детальними та інформативними 
для поглибленого вивчення теми, особливо цікаві та розгорнуті схеми можна конструювати при викладанні клінічних дисциплін. Також студент має можливість додатково опрацьовувати літературні джерела та на основі вивченого теоретичного матеріалу доповнювати схему необхідною інформацією. Результативною дією з боку викладача буде пропозиція студентам скласти структурно-логічну схему разом, ігноруючи догматичний виклад вже підготовленого навчального матеріалу. Краще це здійснити саме на практичному занятті, де кількість студентів у бригаді не перевищує 6-8 осіб. У даному випадку кожен із учасників процесу складання схеми буде залучений до пошуку логічних зв'язків між явищами та поняттями, звертатися до наукових літературних джерел та осмислювати отриману інформацію; кожен може виступити із власною точкою зору та відстояти їі.

Висновки. Вищенаведені шляхи активізації пізнавальної діяльності студентів можна сміливо назвати одними з найефективніших у педагогічній практиці викладача. Кожен педагог у процесі викладацької роботи постійно аналізує та досліджує рівень засвоєння запропонованого навчального матеріалу своєю аудиторією. Навчити майбутню медичну сестру клінічному мисленню означає постійно пропонувати різні методи моделювання дій медичної сестри в конкретній ситуації, формувати спостережливість,

\section{СПИСОК ЛІТЕРАТУРИ}

1. Демиденко В. І. Питання підготовки та проведення ліцензійного іспиту «Крок М. Сестринська справа» / В. І. Демиденко // Медсестринство. - 2019. - № 3. - С. 22-23.

2. Лучишин Н. Ю. Значення дисципліни «Основи медсестринства» у формуванні професійних компетентностей студентів медичного коледжу / Н. Ю. Лучишин, Л. А. Огарьова // Медсестринство. - 2021. - № 1. - С. 51-53.

3. Лимар Л. Є. Професійні компетенції та особистісні якості медичних сестер / Л. Є. Лимар, А. С. Каршунова // Медсестринство. - 2020. - № 4. - С. 27-29.

4. Johnson R. H. Meta-Level Approach to the Problem of Defining «Critical Thinking» / R. H. Johnson, B. A. Hamby // Argumentation. - 2015. - Vol. 29.

5. Варава О. Б. Діагностика готовності викладачів щодо розвитку інформаційно-аналітичної компетентності майбутніх медсестер / О. Б. Варава // Медсестринство. 2018. - № 4. - С. 10-12.

6. Дичаківська І. М. Інноваційні педагогічні технології / І. М. Дичаківська. - К. : Академвидав, 2004. - 352 с.

7. Макуріна Г. І. Бінарна лекція як інноваційна педагогічна технологія у сучасній вищій освіті / Г. І. Макурі- вміння узагальнювати дані та самостійно осмислювати проблему, робити висновки, розвивати в собі здібності до самоконтролю та самоаналізу. За умов швидкого розвитку новітніх технологій в медицині від працівника цієї галузі потребують нестандартних здібностей мислення для створення чогось нового, раніше невідомого. Відомо, що здібності людини поділяють на види за змістом та характером діяльності: розрізняють загальні й спеціальні здібності. Сьогодні від медичного працівника будь-якого рангу вимагають не тільки загальні розумові здібності, а й загальні вміння планувати, організовувати та реалізовувати втручання, проводити диференціальний аналіз ознак, симптомів та ін.; оволодівати новими прийомами роботи та боротися зі складнощами на шляху до мети. Спеціальні здібності визначено тими об'єктивними вимогами, які ставить перед працівником медицина як галузь. Спеціальні здібності $\in$ синтезом певних властивостей особистості, що формують її готовність до активної та продуктивної діяльності. Тому головне завдання сучасного педагога на сьогодні - сформувати зрілу особистість з молоді, яка приходить у ЗВО отримати знання та вміння професії, вказати шляхи до самовдосконалення та постійного ментального розвитку, сформувати мотивацію не тільки до вивчення програмних дисциплін, але й для майбутньої професійної діяльності в цілому.

на, В. А. Візір // Актуальні питання підвищення якості освітнього процесу : зб. тез наук.-практ. конф. з міжнар. участю, 11 травня 2018 р. - Івано-Франківськ : ІФДМУ, 2018. - С. 53.

8. Буряк В. Керування самостійною роботою студентів / В. Буряк // Вища школа. - 2001. - № 4-5. - С. 48-52.

9. Сухова Н. А. Проблемна лекція - один із методів творчого мислення [Електронний ресурс] / Н. А. Сухова. Режим доступу : http://osvita.ua/school/lessons_summary/ edu_technology/24208/.

10. Теслюк В. М. Проблемна лекція як найоптимальніша форма навчання у вищій школі / В. М. Теслюк, М. М. Коваль // Науковий вісник Національного університету біоресурсів і природокористування України. - 2014. Вип. 199 (1). - С. 371-375. - (Серія «Педагогіка, психологія, філософія»).

11. Чернілевський Д. В. Педагогіка та психологія вищої школи : навчальний посібник для студентів ВНЗ / Д. В. Чернілевський, М. І. Томчук. - Вінниця : Вінницький соціально-економічний інститут Університету «Україна». - 2006. - 402 c. 